\title{
EKSPRESI PENDORONG YANG MENGANDUNG ISU BUDAYA SPESIFIK DALAM TEKS TERJEMAHAN SERIAL YOUTUBE MALAM MINGGU MIKO
}

\author{
Ilham \\ Universitas Muhammadiyah Palangkaraya \\ Jalan RTA. Milono Km. 1,5, Palangka Raya, Indonesia \\ *Pos-el: ilhamroy88@gmail.com
}

\begin{abstract}
Abstrak
Saat ini, teknologi membantu kita untuk membuat hidup lebih mudah. Namun, keberadaan teknologi kadang menimbulkan masalah besar seperti contoh otomatisasi subtitle di saluran Youtube pada ekspresi booster yang membantu kita untuk memahami makna Cultural Specific Items (CSI) atau Unsur Budaya Spesifik di serial Malam Minggu Miko 2 karya Raditya Dika. Adanya fitur terjemahan bebas tersebut menimbulkan ketidakjelasan ekspresi booster sehingga menimbulkan kerancuan bagi penonton yang membaca teks sasaran. Penelitian ini adalah metode penelitian kualitatif dengan studi kasus terpancang pada episode Malam Minggu Miko 2: Cosplay Sakura yang telah ditonton lebih dari satu juta pemirsa. Hasil penelitian ini menunjukkan bahwa ekspresi booster pada tuturan tokoh dalam subtitle youtube dipengaruhi oleh aspek multimodalitas khususnya dalam mentransfer Unsur Budaya Spesifik dengan melihat wacana dalam teks.
\end{abstract}

Kata kunci: Booster expression, Unsur Budaya Spesifik, Otomatisasi subtitle youtube, Malam Minggu Miko 2

\section{The Analysis of Cultural Specific Item Issues which Contain Booster Expression in the Target Text on} Youtube Series Malam Minggu Miko

\begin{abstract}
Nowadays, technology helps us to make life easier. However, the existence of technology sometimes causes significant problems such as subtitle automation on YouTube channels on booster expressions that help us to understand the meaning of Cultural Specific Items (CSI) or Specific Cultural Elements in the Malam Minggu Miko 2 series by Raditya Dika. The existence of the free translation feature raises the unclear expression of the booster, confusing the audience reading the target text. This research is a qualitative research method with a case study embedded in the Sunday Night episode Miko 2: Cosplay Sakura which has been watched by more than one million viewers. The results of this study indicate that booster expressions in the speech of characters in YouTube subtitles are influenced by aspects of multimodality, especially in transferring Specific Cultural Elements by looking at discourse in the text.
\end{abstract}

Key Words: ekspresi booster, Cultural Specific Items, automation subtitle on youtube, Malam Minggu Miko 2

\section{PENDAHULUAN}

Ekspresi booster atau ekspresi pendorong adalah ekpresi yang digagas oleh Hyland (1998, 2005). Ia merupakan salah satu ekspresi dari metadiscourse. Metadiscourse sendiri adalah penanda yang digunakan oleh setiap penulis dalam sebuah karya tulisan yang berfungsi untuk membangun interaksi antara penulis dan pembaca (Gholami, M, Tajalli, G, Shokrpour, 2014), dampak pemaknaan teks dan mengikat emosi antara kedua belah pihak \{Formatting Citation\}. Bahkan, penanda tersebut digunakan sebagai penanda klaim akan sesuatu yang diyakini oleh si penutur, lalu kemudian diujarkan kepada mitra tutur (Holmes, 1988; K. Hyland, 1998).

Ekspresi pendorong tersebut juga memberikan dampak pada perbedaan lintas budaya yang ada di masyarakat. Di zaman yang serba modern seperti sekarang ini, segala informasi dapat terserap hanya dengan menggunakan gawai pintar, maka semua orang dapat melihat dan mendengar hal-hal yang di luar mungkin wajar, namun tabu menurut norma yang ada di daerahnya. 
Lebih lanjut, dengan adanya kemajuan teknologi seperti itu, semua orang dapat menikmati hiburan, salah satunya hiburan melalui video adalah melalui kanal di Youtube.

Semenjak Youtube menghadirkan fitur beta Auto-caps di tahun 2009 yang hingga sekarang disebut subtitle (subtitle), kesulitan penonton dalam menghadapi teks sumber sedikit terobati. Hal itu dikarenakan semakin bervariatifnya konten-konten bermutu yang ada di youtube, hal itu menjadi tren di era sekarang dalam kemajuan pada dunia penerjemahan.

Beberapa penelitian terkait booster khususnya dalam penerjemahan yang berkaitan pemanfaatan bidang teknologi dan unsur budaya spesifik masih kurang menjadi perhatian oleh peneliti. Namun, dalam penelitian lima tahun terakhir pada aspek linguistik dan penulisan akademik telah banyak dilakukan seperti penggunaan variasi penggunaan booster dalam skop akademik dan pragmatik (Demir, 2017; Dontcheva-navratilova, 2016; Ilham, Nababan, Kristina, \& Wiratno, 2018, 2019; Kondowe, 2014; Salichah, Irawati, \& Basthomi, 2015; Sanjaya, 2013; Yeganeh, Heravi, \& Sawari, 2015), lalu penelitian dengan pendekatan multimodalitas dalam koteks metadiskursif (Ilham, Bulkani, Darlan, 2018). Sehingga, dari beberapa tinjauan penelitian sebelumnya di atas, dapat diamati bahwa penelitian yang mengkaji tentang analisis ekspresi booster yang menekankan unsur budaya spesifik masih terbatas. Meskipun, pada penelitian sebelumnya ilham, dkk (2018) sudah membahas pada kajian penelitian dalam sebuah brosur promosi namun hal tersebut masih terbatas pada kata-kata atau frasa yang memberikan nilai jual.

\section{TEORI}

Para pakar di bidang penerjemahan telah mendefinisikan berbagai teori tentang definisi tentang penerjemahan sebagai sebuah alih pesan atau proses pergantian suatu teks yang berupa amanat dari bahasa sumber ke bahasa sasaran dengan mengungkapkan makna dan gaya bahasanya (Catford, 2000; Kridalaksana, 1985).

Penerjemah akan mengalami berbagai tantangan dan kendala dalam menerjemahkan unsur budaya pada teks sumber kepada teks sasaran, khususnya budaya spesifik. Hal itu disebabkan oleh penerjemah berperan sebagai jembatan/ mediator komunikasi antara pembawa pesan dan penerima pesan (Hervey, Sándor \& Higgins, 1992; Nababan, 2008), sehingga, tentu saja yang dibawa oleh penerjemah adalah bahasa. Bahasa sendiri tidak lepas dari budaya (Snell-Hornby, 1988).

Dengan demikian, secara tidak langsung gaya bahasa yang yang ada pada bahasa sumber ke bahasa sasaran tidak boleh berubah sehingga patut dipertimbangkan (Nababan, 2008, hal. 12, 2016, hal. 21), serta budaya yang ada pada bahasa sumber juga harus disesuaikan dengan konteks pada bahasa sasaran. Lebih lanjut, penerjemahan tidak hanya melibatkan bilingualisme. penerjemahan unsur budaya spesifik ini erat kaitannya pada unsur ekstralinguistik (Bassnett, 2002). Unsur ekstralinguistik adalah hal-hal yang berkaitan dengan aspek sosial dan budaya. Sehingga, sebagai contoh apa yang digagas oleh Nababan mengenai gaya bahasa tersebut adalah misalnya seorang penerjemah diminta untuk menerjemahkan komik anak-anak dari bahasa Inggris ke bahasa Indonesia, tentu saja selain bahasa yang berbeda budaya pergaulan dan gaya komunikasi antara penulis komik dan pembaca sasaran pada umumnya anak-anak berbeda. Terlebih lagi, 
tidak salah menurut Duff dalam Nababan (Nababan, 2016, hal. 20-21) bahwa “.... penerjemah mestinya mempertimbangkan baik-baik disiplin ilmu apa yang dia sedang kerjakan (baca: terjemahkan), karena dia harus tahu kepada siapa terjemahannya tersebut diperuntukkan dan bagaimana tingkat kemampuan dari pembacanya...". Lebih lanjut, penerjemah harus peka terhadap unsur linguistik dan tekstual pada bahasa sumber dan sasaran, sehingga tidak ada lagi yang namanya ketidaksepadanan dan ketidakterjemahan.

Newmark (1988, hal. 94) mendefinisikan budaya adalah sebagai sebuah jalan hidup, sedangkan konsep budaya dan budaya spesifik sendiri. Lalu ia pernah menyampaikan sebuah gagasan mengenai taksonomi dari unsur budaya asing yakni :1) Ekologi (flora dan fauna), 2) budaya material (makanan, pakaian, dan lain-lain), 3) budaya sosial di masyarakat (lingkungan kerja, komplek perumahan), 4) Organisasi dan aktivitas, 5) kebiasaan sekitar.

Dengan adanya keanekaragaman budaya, khususnya di Indonesia, yang tidak mengherankan kebutuhan akan adanya hiburan lintas budaya dan negara semakin luas, khususnya di era globalisasi sekarang ini semua dalam genggaman tangan melalui sebuah gawai.

Melalui gawai di tangan pada era milenial, semua dapat dinikmati baik untuk bermain game maupun menonton video di Youtube. Youtube merupakan sebuah sarana untuk menonton video yang dilengkapi channel (saluran) yang memudahkan kita untuk mencari atau berlangganan (subscribe) laman hiburan favorit kita.
Lebih lanjut, berdasarkan data statistik dari Omnicom, jumlah video yang ditonton setiap hari adalah lima juta video.

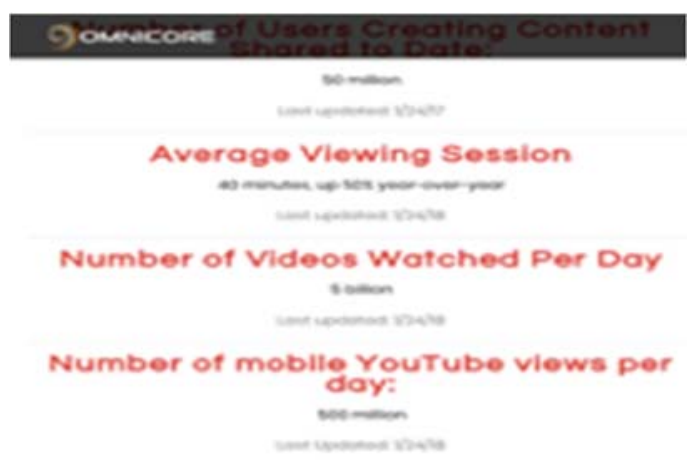

Gambar 1. Jumlah Statistik Penonton Youtube Setiap Harinya

Lebih lanjut, dengan banyaknya jumlah penonton di Youtube memudahkan pembuat video untuk berkreasi dalam membuat serial di Youtube (Labas, Y.N \& Yasmine, 2017, hal. 114), yakni salah satunya adalah serial Malam Minggu Miko yang sudah masuk ke dalam musim ke 2 yang kontennya sangat erat dengan unsur sosial dan budaya yang ada di Indonesia pada umumnya.

Malam Minggu Miko adalah sebuah serial komedi, diciptakan dan digagas oleh Raditya Dika. Raditya dika sendiri merupakan seorang penulis novel, pemain komedi tunggal (Stand Up Comedy), penulis konten pada blog www.radityadika.com, penulis naskah film, juri pada sebuah acara komedi.

Lebih lanjut, pemilihan serial tersebut sebagai subyek pada penelitian ini adalah karena akun saluran Youtube Raditya Dika (Malam Minggu Miko 2) telah mencapai lebih dari jutaan penonton dan pelanggan yang menikmati kontennya (https : $/ / \mathrm{www}$.youtube.com/watch? $\mathrm{v}=$ 3Uh_uVDhwjA). Kemudian, durasi waktu serial ini adalah selama 10 menit 57 detik dan dirilis pada tanggal 26 Oktober 2013. Terlebih lagi, Pemilihan serial tersebut 
dikarenakan banyak unsur budaya campuran Indonesia dan Jepang.

Terlebih lagi, pemilihan serial tersebut memunculkan banyak sekali unsur budaya spesifik baik dari budaya Indonesia, maupun budaya Jepang.

Sekilas mengenai serial tersebut, Malam Minggu Miko 2 menceritakan tentang pengalaman absurd malam minggu yang dirasakan oleh Miko (Raditya Dika) dengan temannya Dovi (Andovi Da Lopez), dan pembantunya bernama Anca Bianca (Hadian Saputra). Episode yang ada di dalam penelitian ini adalah mengenai kompetisi Cosplay yang diselenggarakan oleh teman baik Miko yaitu Sakura.

Meskipun serial komedi tersebut cukup menghibur bagi masyarakat Indonesia alangkah lebih baiknya jika konten hiburan tersebut dapat dinikmati untuk segala kalangan. Salah satu langkah awal untuk dapat memahami konten tersebut adalah dengan mengaktifkan fitur subtitle. Adapun pertanyaan penelitian pada studi terkait booster dalam penelitian ini adalah bentuk ekspresi booster dalam menekankan unsur budaya spesifik dalam serial Malam Minggu Miko 2: Cosplay Sakura?

\section{METODE}

Penelitian ini berpijak pada pendekatan kualitatif deskriptif dengan studi kasus terpancang, dan untuk mendeskripsikan jawaban dari pertanyaan penelitian terkait bentuk bagaimana ekspresi booster memiliki peran dalam menekankan unsur budaya spesifik dalam serial Malam Minggu Miko 2: Cosplay Sakura melalui Yotube. Data dikumpulkan dengan menggunakan metode simak, catat, dan tangkap (capture) bagian yang mengandung booster unsur budaya spesifik.

Lebih lanjut, yang dapat menentukan apakah itu data atau bukan adalah oleh penelitinya sendiri. Selanjutnya, penelitian ini bersifat purposive sampling.

Sumber data pada penelitian ini adalah serial Youtube Malam Minggu Miko 2: Cosplay Sakura dan hasil terjemahan otomatisasi subtitle Youtube yang berkaitan dengan kata, frasa, klausa dan kalimat yang mengandung unsur eskpresi booster pada penekanan unsur budaya spesifik berdasarkan bukti linguistik berupa tuturan penutur dan mitra tutur.

Sumber data dikumpulkan dan diklasifikasi dari Tsu (Teks sumber) dan Tsa (Teks sasaran) dari seluruh pemain penting yang terlibat langsung dalam serial Malam Minggu Miko 2: Episode Cosplay Sakura.

Teks Sumber pada penelitian ini adalah bahasa Indonesia, Bahasa Jepang dan Teks sasarannya adalah bahasa Inggris. Bahasa Inggris yang dihasilkan merupakan bahasa Inggris yang diolah dari otomatisasi dari pengaturan manual laman Youtube.

\section{HASIL DAN PEMBAHASAN}

Serial Malam Minggu Miko musim ke dua episode Cosplay Sakura menggambarkan tentang situasi Miko dan Dovi yang mengikuti lomba Cosplay yang diadakan oleh teman Miko yakni Sakura.

Namun, di setting yang lain menggambarkan tentang Anca, pembantu Miko yang tengah menderita sakit karena keracunan makan shusi basi yang dikirim dari Jepang oleh teman Dovi. Karakter lain yang terlibat adalah Sakura dan Pembawa Acara.

Booster yang ada di dalam penelitian ini mengacu kepada kata, frasa atau klausa bahkan kalimat yang menunjukan penekanan pada klaim atas sesuatu dasar yang diyakinkan oleh penutur khususnya dalam unsur budaya spesifik. Seperti pada contoh datum yang disajikan pada gambar 2.1: 


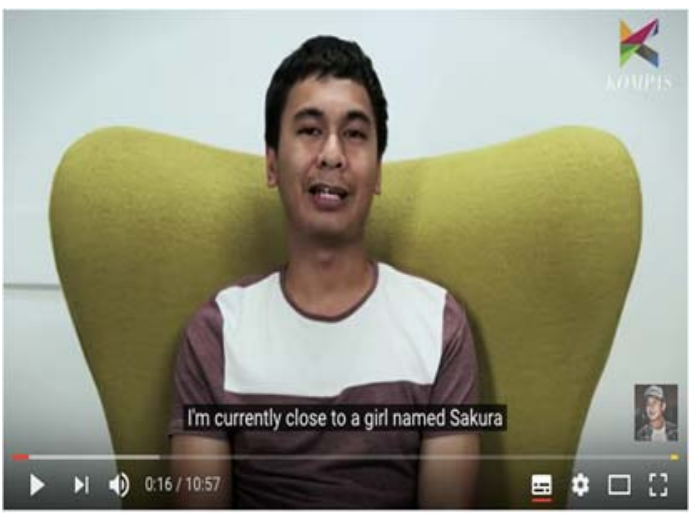

Gambar 2.1. Pernyataan Miko

Berikut adalah tuturan yang dihasilkan oleh Miko.

\section{Tsu "Gue lagi dekat sama Sakura" Tsa "I'm currently close to a girl named Sakura”}

Situasi tuturan yang dihasilkan dalam memproduksi booster yang bersifat pernyataan (stating) oleh Miko disampaikan kepada para penonton bahwa dia sedang dekat dengan seorang perempuan bernama Sakura. Kedekatan tersebut memang menjadi ciri serial tersebut, karena serial Malam Minggo Miko menceritakan tentang perjalanan Miko untuk mencari pasangan.

Lebih lanjut, penamaan Sakura digunakan untuk menyesuaikan tema yang diangkat yaitu budaya Jepang mengenai Cosplay (meniru tokoh-tokoh Jepang).

Kemudian, pada episode ini Miko yang lagi berusaha dekat dengan Sakura ingin mengikuti perlombaan Cosplay yang diadakan oleh Sakura, yakni Kompetisi Cosplay dan ada juri serta reporter televisi yang terlibat untuk mengikuti kompetisi tersebut.

Terlebih lagi pada situasi tuturan yang diujarkan oleh Miko juga mengandung pernyataan yang bersifat budaya Jepang secara implisit yakni nama "Sakura" pada tokoh seorang perempuan yang didekati oleh Miko.

Ekspresi booster yang ada pada tindak ujaran tersebut menekankan pada frasa "gue lagi dekat" yang kemudian mereferen kepada Sakura yakni perempuan yang sedang dekat dengan Miko.

Sakura sendiri berasal dari nama-nama yang familiar di Jepang misalnya nama orang atau nama benda. Berikut datum 2 pada Gambar 2.2:

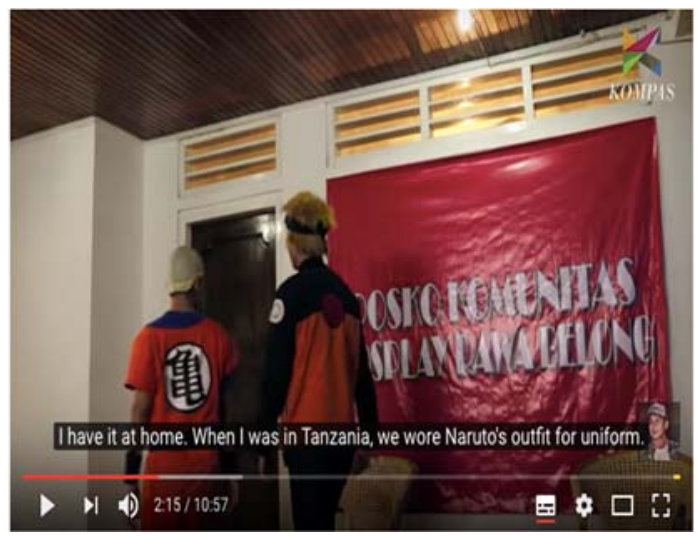

Gambar 2.2. Contoh referen nama-nama benda yang mengandung unsur budaya

Situasi ujaran pada scene ini terjadi saat Dovi dan Miko ke lokasi tempat pelaksanaan lomba Cosplay tersebut.

Dovi setuju untuk ikut bergabung mengikuti lomba karena dia memiliki pengetahuan di bidang Anime, Naruto.

Lebih lanjut, tampak pada gambar tersebut terlihat Miko bergaya cosplay seperti Kuririn salah satu pemain dalam serial kartun Dragon Ball dan Dovi bergaya seperti Naruto.

Peristiwa tutur itu menggambarkan akan pengetahuan Dovi yang lebih memiliki pengalaman di bidang Cosplay dibanding dengan Miko yang hanya ikut-ikutan karena ingin mendekati Sakura. 
Berikut adalah tuturan yang dihasilkan oleh Dovi (Datum 2 pada Gambar 2.2).

Tsu "Gue punya di rumah. Waktu gue di Tanzania, kita seragam sekolahnya pakai baju Naruto kayak gini"

Tsa "I have it at home. When I was in Tanzania, we wore Naruto's outfit for uniform"

Tuturan yang dihasilkan oleh Dovi tersebut bersifat partikel booster claim (pengakuan), answering (menjawab) serta stating (menyatakan) dalam menjawab pertanyaan dari mitra tutur yakni Miko yang bertanya dari mana baju-baju tersebut berasal.

Lebih lanjut, karena genre yang ada pada serial ini adalah genre komedi. Sehingga, yang ditonjolkan adalah aspek humor yang dibangun dengan menggunakan kata, mimik dan pakaian sebagai multimodalitas dalam melihat wacana.

Kemudian, booster yang ditonjolkan adalah pada Tsu "gue punya di rumah". Tuturan tersebut diterjemahkan melalui otomatisasi Youtube menjadi "I have it at home. Tidak ada pergeseran pada tuturan tersebut baik secara gramatikal maupun leksikal.

Tuturan Tsu tersebut mengandung booster klaim yang diakui oleh Dovi. Secara langsung dituturkan dengan yakin oleh Dovi mengenai baju cosplay yang dia miliki.

Lebih lanjut, Tsu selanjutnya dalam scene datum 2 tersebut “....Waktu gue di Tanzania, kita seragam sekolahnya pakai baju Naruto kayak gini" diterjemahkan oleh Youtube menjadi "...When I was in Tanzania, we wore Naruto's outfit for uniform". Ekspresi booster yang ada pada tuturan di atas adalah pada klausa "... When I was in Tanzania". Sehingga, sifat pada booster di atas adalah berupa pernyataan (stating) yang dituturkan oleh Dovi kepada Miko selaku mitra tutur.

\section{Berikut adalah Datum 3 pada gambar}

\section{3:}

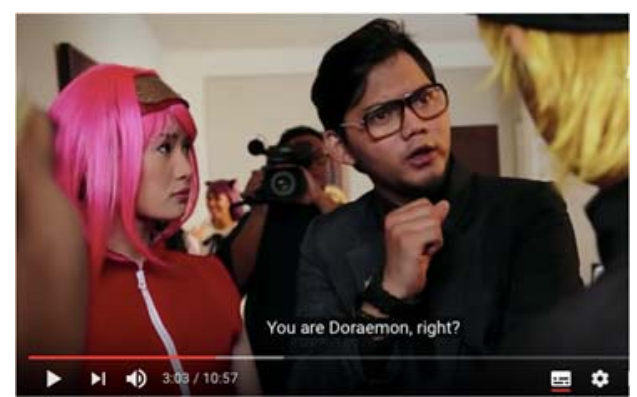

Gambar 2.3. Juri dan pembaca acara sedang menanyakan kostum yang digunakan Dovi

Seperti yang diuraikan di atas, serial ini mengandung banyak unsur humor dan aspek budaya spesifik yang ada baik berupa nama makanan, nama tokoh Anime \& Manga, serta gimmick para tokoh.

Pada contoh datum 3, peristiwa tutur terjadi di dalam tempat kompetisi yang mana saat Dovi dan Miko datang, Dovi ditanyakan tentang bergaya menjadi siapa, dan tiba-tiba secara langsung si Juri selain menebaknebak secara asal bahwa si Dovi ini bergaya seperti Doraemon, seperti berikut:

\section{Tsu Kamu jadi Doraemon, ya??"}

\section{Tsa You're Doraemon, right?"}

Eskpresi booster yang ada pada tuturan berisi pertanyaan (questioning) dan dugaan (guessing) dari pembawa acara yang merangkap sebagai judge pada kompetisi tersebut.

Penekanan (boosting) yang ditunjukan pada tuturan tersebut adalah pada pernyataan si juri "kamu jadi Doraemon, ya??”. Lebih lanjut, “..ya” yang dimaksud seolah-olah tahu bahwa si Dovi tersebut 
bergaya seperti Doraemon. Hal ini menjadi tidak begitu jelas karena adanya keraguan dari juri itu sendiri. Sehingga memaksa mitra tuturnya untuk mengakui (claiming) pada ujaran yang diberikan. Menurut kami, hal itu masuk dalam kategori logis booster untuk menutupi keraguan si juri.

Hal ini ditunjang dengan aspek multimodal yang disertai tuturan selanjutnya karena Dovi menggunakan kumis pada wajahnya.

Seperti kita ketahui bahwa Doraemon merupakan tokoh Anime \& Manga yang sangat terkenal di Jepang dan memang memiliki ciri kumis Panjang karena dia merupakan robot yang dikirim untuk membantu Nobita. Tokoh Doraemon tersebut merupakan karakter yang diciptakan oleh Fujiko F. Fujio (Gambar 2.4)

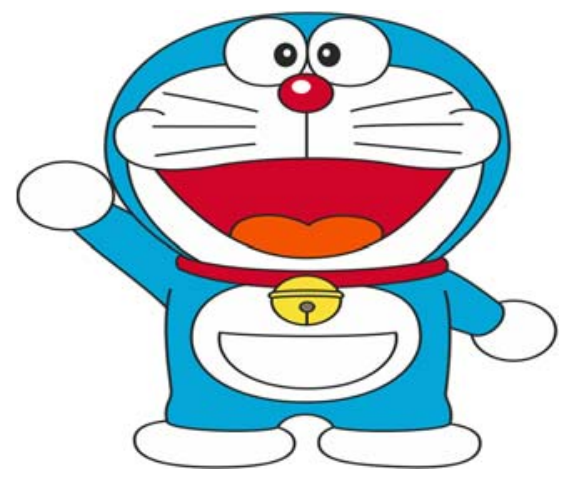

Gambar 2.4. Gambar tokoh serial Anime \& Manga Doraemon

Adapun mengenai aspek terjemahan yang dihasilkan dari tuturan berupa subtitle hasil otomatisasi Youtube tidak ada pergeseran makna yang ada meskipun bergeser secara gramatikal namun tidak merubah makna dan pesan cukup tersampaikan. Teknik penerjemahan yang digunakan adalah padanan lazim (established equivalence) jika meminjam teori Molina \& Albir (2002) seperti kata
Doraemon yang tidak dirubah dan tetap mempertahankan ideologi foreinisasi. Hal itu mungkin diakibatkan karena Doraemon telah dikenal masyarakat luas. Hal ini menjadi berbeda saat pada contoh datum 4 Gambar 2.5. berikut:

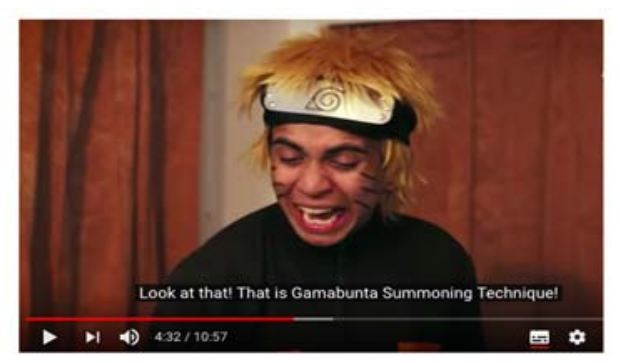

Gambar 2.5. Dovi memamerkan gerakan (gimmick) yang dia praktekan dari Serial kartun Naruto

Peristiwa tutur yang terjadi di atas adalah saat Dovi maju ke depan panggung untuk mempraktekan sebuah gerakan atau penampilan tokoh yang dia ikuti. Pada kali ini Dovi memamerkan jurus yang sering digunakan oleh Naruto.

Ekspresi booster yang ada pada peristiwa tutur tersebut diproduksi oleh Dovi saat memperagakan jurus Naruto, sebagai berikut:

\section{Tsu "Lihat itu! Itu adalah jurus memanggil katak Marabunta!"}

\section{Tsa "Look at that! That is Gamabunta Technique"}

Booster yang ada pada tuturan di atas adalah pada klausa “....Itu adalah jurus memanggil katak Marabunta!”. Hal itu lagilagi diperlukan gambar penjelasan atau tambahan pada serial tersebut. Menurut kami, hal itu bisa terjadi agar serial dan 
tuturan di atas dapat diterima oleh penonton (lihat Gambar 2.6)

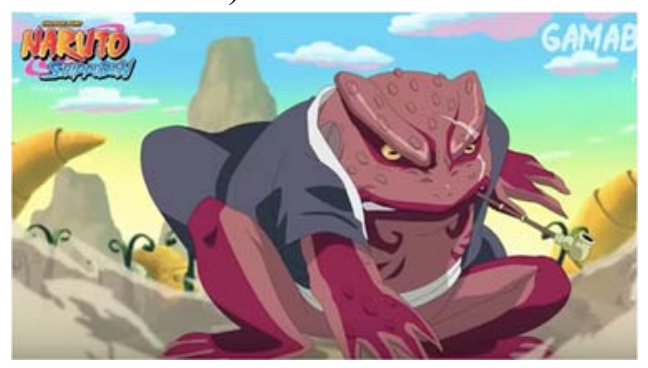

Gambar 2.6. Katak Marabunta pada serial Naruto

Dilihat dari segi penerjemahan pada ekspresi booster, tidak ada pergeseran pada makna dari Tsu ke Tsa. Namun mestinya, karena nama jurus tersebut belum tentu familiar bagi pembaca atau penonton dapat diganti dengan bahasa baik kata yang lebih berterima. Tentu saja pada hal ini ideologi yang digunakan adalah foreignisasi.

Ada hal menarik yang juga terjadi pada saat peristiwa tutur yang sama terjadi pada Datum 5 yang disajikan pada Gambar 2.7 di bawah

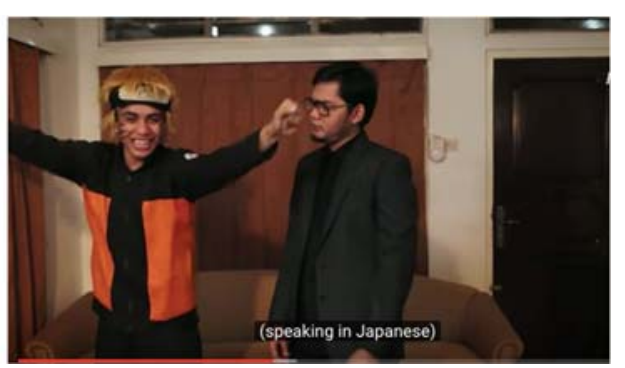

Gambar 2.7. Tuturan dari Dovi tidak mampu diterjemahkan oleh mesin otomatisasi Youtube

Peristiwa tutur yang terjadi di waktu yang sama dengan datum 4 adalah saat Dovi ingin maju mempertunjukan jurus yang sering Naruto gunakan, namun dengan menggunakan bahasa Jepang.

\section{Tsu “Boku wa Naruto Desu, Hokage! Hokage! Hokage!!” \\ Tsa "Speaking Japanese"}

Dalam peristiwa tindak tutur tersebut sang penutur, Dovi menyebutkan salah satu salam perkenalan diri namun menggunakan bahasa Jepang.

Booster yang ada pada ekspresi salam tersebut adalah menyatakan stating dan boasting (membual/berbohong) dikarenakan bahwa dia memperkenalkan diri, namun yang dikenalkan adalah bukan diri dia, namun Naruto, pada tuturan Tsu "Boku wa Naruto Desu." yang artinya jika dalam Bahasa Indonesia diterjemahkan bebas adalah "perkenalkan nama saya Naruto". Lebih lanjut, penutur juga menuturkan kata “..Hokage..” sebanyak tiga kali. Hal tersebut juga menandakan bahwa dia membual bahwa dia Naruto memiliki gelar Hokage.

Secara keseluruhan ekspresi booster yang ada adalah pada kalimat perkenalan diri bukan dalam satuan partikel.

Terlebih lagi, dalam aspek penerjemahan, yang sangat disayangkan. Otomatisasi Youtube tidak mampu menerjemahkan unsur Tsu yang ada pada bahasa sumber terlebih lagi hal tersebut berkaitan dengan unsur budaya spesifik dapat dilihat pada gambar datum 8 .

Menurut penulis, teknik penerjemahan yang disarankan adalah menggunakan teknik adaptasi Molina dan Albir (2002) dan tidak hanya ditulis speaking Japanese, karena tuturan tersebut memuat bagaimana budaya Jepang dalam memperkenalkan diri (Japanese greeting).

Dampak dari ketidakterjemahan tersebut memberikan kurangnya kualitas terjemahan yang dihasilkan yang semestinya memuat aspek keakuratan (accuracy), 
keberterimaan (acceptability), dan keterbacaan (readability) seperti yang diusulkan oleh Nababan, dkk (2012).

Adapun budaya Indonesia juga hadir dalam tingkah perilaku unsur humor yang ditonjolkan bagaimana penggambaran pembantu pada umumnya di Indonesia (lih. Gambar 2.8.)

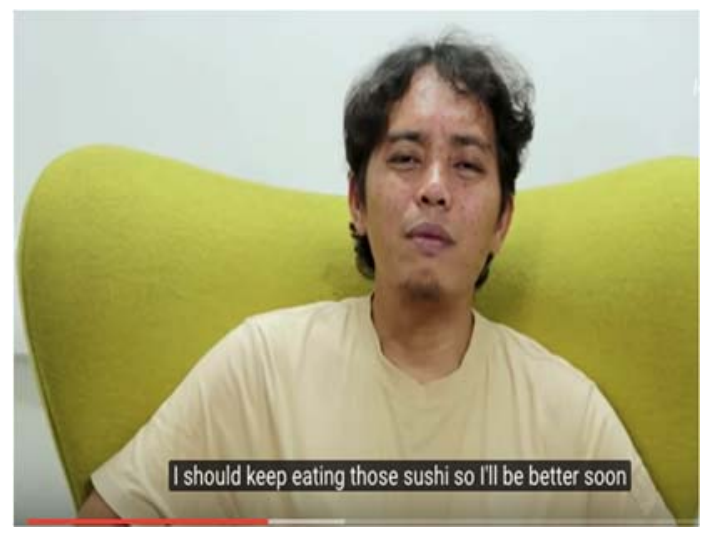

Gambar 2.8. Tuturan dari Anca merupakan bentuk kepolosan Anca selaku pembantu dari kampung

Eksperesi booster pada tuturan di atas adalah salah satu dari situasi peristiwa tutur yang terjadi saat Anca merasakan efek keracunan sushi basi yang dikirim langsung oleh rekan Dovi langsung dari Jepang. Namun, ternyata ikan sushi tersebut dimakan Anca karena "merasa" sayang pada makanan ikan tersebut.

Budaya sayang dalam membuangbuang makanan yang ada merupakan adat istiadat yang biasa dilakukan orang Indonesia. Namun sayangnya, Anca tidak memberi informasi jelas kepada Anca bahwa ikan sushi tersebut sudah basi.

Kemudian, budaya Indonesia untuk memakan ikan sebagai lauk juga diperlihatkan sebagai makanan pokok dan didukung oleh aspek multimodalitas.
Tuturan yang mengandung booster pada peristiwa tutur di atas adalah (lihat Gambar 2.8):

\section{Tsu "Saya harus terus makan sushi biar sehat" \\ Tsa "I should keep eating those sushi so I'll be better soon"}

Booster yang ditekankan adalah bentuk klaim bahwa denga memakan ikan yaitu "biar sehat". Memang dalam budaya Indonesia membudayakan 4 sehat 5 sempurna adalah salah satunya dengan memakan ikan. Namun, Anca tidak mengetahui bahwa ikan sushi tersebut sudah basi karena dikirim jauh dari Jepang.

Booster "biar sehat" tersebut diterjemahkan melalui otomatisasi Youtube mengalami pergeseran menjadi "I'll be better soon", yang jika diterjemahkan dengan teknik literal translation atau harfiah adalah "saya akan segera menjadi lebih baik (sembuh)", dan teknik penerjemahan yang digunakan adalah Amplifikasi (Molina \&Albir, 2002) dengan adanya penambahan informasi namun tidak merubah isi pesan yang terkandung. Terlebih lagi, jika dilihat pada gambar dan cerita latar belakang kondisi Anca tersebut sedang sakit. Jadi, kemungkinan pemilihan klausa tersebut dikarenakan melihat kondisi konteks situasional yang terjadi. Menurut penulis, terjemahan tersebut tidak akurat namun lebih berterima.

\section{PENUTUP}

Dari uraian di atas dapat ditemukan bahwa booster juga dapat memberi peran dalam pewarnaan karakter budaya seseorang pada serial malam minggu Miko.

Booster yang hadir dalam sebuah tuturan pada penelitian ini, dapat berupa 
stating, claiming, boasting, answering, guessing.

Boosterpun dapat digunakan untuk mentrasnfer unsur budaya spesifik pada sebuah tuturan dari penutur.

Pergeseran hasil terjemahan bergantung kepada analisis teknik terjemahan yang digunakan. Dampak perbedaan tekik penerjemahan yang digunakan akan memberikan dampak pada hasil dan kualitas terjemahan.

Booster yang di dalamnya terkandung pagar (hedge) masih kurang menjadi perhatian sehingga dibutuhkan untuk diteliti lebih lanjut oleh kami ataupun juga peneliti yang lain.

Bagi penerjemah, sangat penting untuk memperhatikan booster dalam proses menerjemahkan karena akan memberikan dampak yang cukup luas untuk hasil terjemahan.

\section{DAFTAR PUSTAKA}

Bassnett, S. (2002). Translation Studies.

Diambil dari

https://books.google.co.id/books?id=_s FfEY15u_EC

Catford, J. C. (2000). A Linguistic Theory of Translation. Diambil dari https://books.google.co.id/books?id=u kUwmgEACAAJ

Demir, C. (2017). Competence in lexical boosters and nativeness in academic writing of English : The possible relation. Journal of Language and Linguistic Studies, 13(2), 593-614. Diambil dari https://www.jlls.org/index.php/jlls/arti cle/view/647

Dontcheva-navratilova, O. (2016). CrossCultural Variation in the Use of Hedges and Boosters in Academic Discourse. Prague Journal of English
Studies, 5(1), 163-184.

https://doi.org/https://doi.org/10.1515/

pjes-2016-0009

Eriyanto. (2001). Analisis Wacana:

Pengantar analisis teks media (hal.

396). hal. 396. Diambil dari

https://catalogue.nla.gov.au/Record/15 06004

Gholami, M, Tajalli, G, Shokrpour, N. (2014). An Investigation of metadiscourse markers in English medical texts And their Persian Translation Based On Hyland's Model. European Journal of English Language and Literature Studies, 2(2), $1-41$.

Hervey, Sándor \& Higgins, I. (1992). Thinking Translation: A course in translation method: French to English. London, New York: Routledge.

Holmes, J. (1988). Doubt and Certainty in ESL Textbooks. Applied Linguistics, 9(1), 21-44.

https://doi.org/https://doi.org/10.1093/ applin/9.1.21

Hui, J., \& Na, B. (2008). Use of metadiscourse markers in allocating SLA learners ' attention. 5(11), 1-5. Hyland, K. (1998). Hedging in Scientific Research Articles. In Pragmatics \& Beyond New Series. Amsterdam: John Benjamins.

Hyland, Ken. (1998). Boosting, hedging and the negotiation of academic knowledge. Text, 18(3), 349-382. https://doi.org/10.1515/text.1.1998.18. 3.349

Hyland, Ken. (2000). Hedges, boosters and lexical invisibility: Noticing modifiers in academic texts. Language Awareness, 9(4), 179-197. https://doi.org/10.1080/096584100086 67145 
Hyland, Ken. (2005). Stance and engagement: A model of interaction in academic discourse. Discourse Studies, 7(2), 173-192. https://doi.org/10.1177/146144560505 0365

Ilham, Bulkani, Darlan, S. (2018). Booster Expression in Image Building of Green Islamic Campus Program at the Promotional Brochure of Universitas Muhammadiyah Palangkaraya : Can it Reach the Market Share in the Era of Industry 4.0 ? Proceedings of International Conference "Internationalization of Islamic Higher Education Institutions Toward Global Competitiveness," 400-408. Diambil dari http://jurnal.unissula.ac.id/index.php/b ksptis/article/view/3600

Ilham, I., Nababan, M. R., Kristina, D., \& Wiratno, T. (2018). The Evolution of Booster on the Assertive Speech Act Used in Two Decades Version of Translation. Advances in Social Science, Education and Humanities Research, volume 166 4th PRASASTI International Conference on Recent Linguistics Research (PRASASTI 2018), 166(Prasasti), 546-551. https://doi.org/10.2991/prasasti18.2018 .100

Ilham, I., Nababan, M. R., Kristina, D., \& Wiratno, T. (2019). The Analysis of Booster Expression in Complaining Speech Act. Advances in Social Science, Education and Humanities Research, volume 338 Fifth PRASASTI International Seminar on Linguistics (PRASASTI 2019) The, 338(Prasasti), 344-351.

https://doi.org/10.2991/prasasti19.2019 .59

Kondowe, W. (2014). Hedging and boosting as interactional metadiscourse in literature doctoral. International Journal of Language Learning and Applied Linguistics World (IJLLALW), 5(March), 214221.

Kridalaksana, H. (1985). Fungsi bahasa dan sikap bahasa. Diambil dari https://books.google.co.id/books?id=h yHPuwEACAAJ

Labas, Y.N \& Yasmine, D. I. (2017). Komodifikasi di era masyarakat jejaring: Studi kasus YouTube Indonesia. 4(2), 104-1199. https://doi.org/https://doi.org/10.22146 /jps.v4i2.28584

Nababan. (2008). Kompetensi penerjemahan dan dampaknya pada kualitas terjemahan. Surakarta: UNS Press.

Nababan, M. R. (2016). Teori menerjemah Bahasa Inggris. Yogyakarta: Pustaka Pelajar.

Newmark, P. (1988). A textbook of translation. Diambil dari https://books.google.co.id/books?id=A BpmAAAAMAAJ

Pérez-llantada, C. (2003). Communication Skills in Academic Monologue Discourse. Círculo de lingüística aplicada a la comunicación, (15), 115.

Salichah, I., Irawati, E., \& Basthomi, Y. (2015). Hedges and Boosters in Undergraduate Students ' Research Articles. Jurnal Pendidikan Humaniora, 3(2), 154-160. Diambil dari http://journal.um.ac.id/index.php/jph/a rticle/view/4855

Sanjaya, I. N. S. (2013). Hedging and Boosting in English and Indonesian Research Articles. The Pennsylvania State University. 
Telaga Bahasa Vol.8, No.2, Oktober 2020

Snell-Hornby, M. (1988). Translation studies: An integrated approach. Diambil dari

https://books.google.co.id/books?id=ei CjQgAACAAJ

Yeganeh, M., Heravi, I., \& Sawari, A. (2015). Hedge and Booster in Newspaper Articles on Iran's Presidential Election: A Comparative Study of English and Persian Articles. Procedia - Social and Behavioral Sciences, 192, 679-683.

https://doi.org/10.1016/j.sbspro.2015.0 6.103 